Cinémas

Revue d'études cinématographiques

Journal of Film Studies

\title{
Metafiction, Pararealism and the "Canon" of Canadian Cinema
}

\section{Deborah Knight}

Volume 3, numéro 1, automne 1992

URI : https://id.erudit.org/iderudit/1001184ar

DOI : https://doi.org/10.7202/1001184ar

Aller au sommaire du numéro

\section{Éditeur(s)}

Cinémas

ISSN

1181-6945 (imprimé)

1705-6500 (numérique)

Découvrir la revue

Citer cet article

Knight, D. (1992). Metafiction, Pararealism and the "Canon" of Canadian Cinema. Cinémas, 3(1), 125-146. https://doi.org/10.7202/1001184ar

\section{Résumé de l'article}

La pensée critique relative aux cinémas canadien anglais et québécois s'est orientée pour une large part vers les tendances réalistes de notre production de fiction - la réalisation de fiction ayant hérité, sur le plan historique, des pratiques du cinéma documentaire canadien. Mais dans la récente production de fiction, on constate que les cinéastes canadiens sont allés au-delà du réalisme social. En effet, l'émergence au Canada anglais et au Québec d'une réalisation qui est métafictionnelle et pararéaliste - dans des films comme $\mathrm{La}$ Femme de l'hôtel de Léa Pool, Roadkill de Bruce Mc Donald et White Room de Patricia Rozema - nous donne non seulemenl l'occasion de repenser les critères qui ont été utilisés pour identifier les films « canoniques ", mais davantage encore de voir comment ces stratégies fictionnelles auto-réflexives, qui d'abord semblent rejeter les normes du réalisme social, sont en fait partie prenante d'une ré-évaluation constante des limites de la fiction. 


\title{
Metafiction, Pararealism and the "Canon" of Canadian Cinema
}

\section{Deborah Knight}

\begin{abstract}
RÉSUMÉ
La pensée critique relative aux cinémas canadien anglais et québécois s'est orientéc pour une large part vers les tendances réalistes de notre production de fiction - la réalisation de fiction ayant hérité, sur le plan historique, des pratiques du cinéma documentaire canadien. Mais dans la récente production de fiction, on constate que les cinéastes canadiens sont allés au-delà du réalisme social. En effet, l'émergence au Canada anglais et au Québec d'une réalisation qui est métafictionnelle et pararéaliste - dans des films comme La Femme de l'hôtel de Léa Pool, Roadkill de Bruce Mc Donald et White Room de Patricia Rozema - nous donne non seulement l'occasion de repenser les critères qui ont été utilisés pour identifier les films «canoniques", mais davantage encore de voir comment ces stratégies fictionnelles auto-réflexives, qui d'abord semblent rejeter les normes du réalisme social, sont en fait partie prenante d'une ré-évaluation constante des limites de la fiction.
\end{abstract}

\begin{abstract}
Critical thinking about the English-Canadian and Quebec cinemas has focused to a large degree on the realist tendencies of our fiction filmmaking-tendencies, it is argued, which fiction filmaking has, historically inherited from Canadian documentary film practices. But in recent fiction filmmaking, Canadian filmmakers have moved beyond social realism. Indeed, the emergence in EnglishCanada and Quebec of filmmaking that is metafictional and pararealist - in films like Léa Pool's La Femme de l'hôtel, Bruce McDonald's Roadkill and Patricia Rozema's White Room - gives us occasion not only to rethink the criteria
\end{abstract}


that have been used to identify "canonic" film, but more importantly to sec how these self-conscious fictional strategies, which initially seem to reject the norms of social realism, are in fact part of an ongoing re-examination of the limits of fiction.

My point of departure is the emergence, in roughly the last seven years, of fiction filmmaking practices which can be described as metafictional or pararealist . The sorts of films that I have in mind challenge the traditional criteria which have served to establish a "canon" of Canadian cinema. What I hope to accomplish in this paper are three things. I want to sketch what have thus far served as acceptable criteria for constructing a canon of Canadian film. In the main part of the paper, I will discuss in some detail three cinematic metafictions to demonstrate how metafictions problematize and in some cases repudiate these criteria. I will return, at the end of the paper, to the question of the canon, primarily to question of the value of a canon and of canonicity, and to suggest an alternative to canon-formation.

If there is such a thing as a "canon" of Canadian cinema, it is a critic's construct. And it has been constructed in relation to fiction filmmaking practices dominated by the conventions, concerns and technology of cinematic realism and naturalism, often called "social realism". Canadian social realism is exemplified in the $60 \mathrm{~s}$ and 70s by films like Nobody Waved Goodbye (Owen, 1964), Le Chat dans le sac (Groulx, 1964), Between Friends (Shebib, 1973), and, moving into the $80 \mathrm{~s}$, by Les Bons débarass (Mankiewicz, 1980). This close connection between fictional forms and technology ought not to surprise : as we know very well, the kinds of films we have made in this country, whether fictional, documentary or experimental, have consistently been tied to specific developments in technology, and to the availability of technology. Cinematic realism and cinematic naturalism in Canada follow from the rise of particular kinds of documentary filmmaking practices and the general ideology of documentary filmmaking best exemplified by Unit B in the 50 s and early $60 \mathrm{~s}$.

Most of the fiction films of the Canadian "canon" can be thought of as bringing together two important tendencies of "realism" : a photographic or cinematographic realism of the sort diagnosed by Bruce Elder, a "realism" based in the technology that produces cinematic images; ${ }^{1}$ and (ii) a particular sort of narrative realism based upon the construction of an internally coherent and plausible 
fictional world, a fictional world that aspires to be taken as essentially consistent with our social world because actions are linked together temporally and causally, a fictional world in which characters act for the same sorts of reason that cause us to act in the social world. This is more true of English-Canadian fiction filmmaking than of Quebec fiction filmmaking, but we certainly see this sort of realism in both cinemas. These two tendencies cash out in the naturalism of so much Canadian filmmaking - a social realism informed by the traditions of our documentary film practice in which fictions are understood to capture or depict our actual social conditions. Geoff Pevere puts this aptly when he describes Canadian social realism as "a kind of filmmaking more concerned with documentation (or an impression of it ) than dramatic reconstruction of events" (22). And the centrality of social realism, starting with the documentaries of the $50 \mathrm{~s}$ and remaining with us into the $90 \mathrm{~s}$ in fiction and in docudrama, has contributed to one main critical tendency: the tendency to interpret Canadian films of all sorts as, in the first instance, documents that tell us about our existence - social, national or cultural. The sociological inclination of Canadian film criticism depends on social realism as a film mode.

But there have been a number of challenges to this essentially realist mode of representation. Films as different from one another as La Femme de l'hôtel (Pool, 1984), Speaking Parts (Egoyan, 1989), Jésus de Montréal (Arcand, 1989), Roadkill (McDonald, 1989) and White Room (Rozema, 1990) share this: they all break with dominant realist/naturalist conventions. All the mainstays of social realism - coherence of character psychology, coherence of plot action, the construction of a coherent fictional world - are challenged by the metafictional or pararealist strategies of our contemporary filmmakers. Many of these films are tremendously self-conscious and self-reflexive : they draw attention to themselves as fictional constructs; they play with different and occasionally even inconsistent textual strategies; they question the epistemological and the social role of cinema.

The notion of metafiction came into its own in the $80 \mathrm{~s}$ in the study of literature, and has been variously defined. Here is one way of describing it : metafiction is "a celebration of the (...) creative imagination together with an uncertainty about the validity of its representations; an extreme self-consciousness about language, literary form and the act of writing fictions; a pervasive insecurity about the relationship of fiction to reality" (Waugh, 2). What is crucial here is that the sort of textual self-consciousness and self-reflexivity we find in metafictions has to do with the 
construction of fiction itself. So wherever we find metafictions, we find attentiveness to the narrative form of fiction. And where we find attention paid to the narrative form, we find a recognition that not all narratives are fictions - that both fictional and nonfictional narratives carry with them particular sorts of knowledge claims. The recognition that both fictions and non-fictions raise questions about what sort of knowledge we derive from narratives in turn poses the question of what sort of "reality" narratives depict or represent, and how the picturing or representational relationship between narrative and the world is to be understood. In metafiction, what characteristically occurs is a deliberate problematization of such knowledge claims within the construction of a self-reflexive fiction.

In the context of cinema, we can see metafictional tendencies in films which are self-reflexively about filmmaking and in films that are self-reflexively about story-telling. Cinematic metafictions that are self-reflexively about filmmaking will also, inevitably, be films that are concerned with story-telling : Léa Pool's La Femme de l'hôtel is an example. But the converse does not always hold. Not all cinematic metafictions that are self-reflexively about storytelling will also be about filmmaking as well: as we can see, for instance, in the case of Denys Arcand's Jésus de Montréal. What is shared by both tendencies is an awareness of the metafictionally problematized status of the cinematic image and the representation of character and character action. The cinematographic image has traditionally been taken to give us access to a world of actions which it has attempted, more or less faithfully, to document - or at least to appear to document. In cinematic metafictions, the image is no longer in and of itself any sort of guarantee of objective truth, verisimilitude, or mimetic authenticity.

Léa Pool's La Femme de l'hôtel is an exemplary metafictional film. It is a film about a director making a film, and it is explicitly self-reflexive. The filmmaker, Andréa (Paule Baillargeon), is also La Femme de l'hôtel's first-person voice-over narrator. She speaks about selfhood and identity, about the tension between creating art and documenting reality, about the intricate interconnections between selves and others - this in the context of a film very much concerned with the ways in which language and location shape identity and structure experience. Andréa's struggle, as screenwriter and director, is to create a particular character, to realize, in fiction, the female protagonist for her film, a protagonist who will allow her to examine these concerns by means of the fictional narrative of the film within the film. So Andréa, as artist, uses fiction, uses filmmaking, as a means of 
inquiry into, as a way of studying, certain patterns of experience, reflection and action. Of course, what Andréa is attempting through the creation of her female protagonist is an analogue of what, at another level, Léa Pool is doing through the character of Andréa. This kind of self-reflexivity is paradigmatically metafictional.

But the metafictional nature of La Femme de l'hôtel is not just worked out in terms of plot and characterization. If it were, Pool might just as well have written a novel as made a film. But she made a film, and La Femme de l'hôtel is indeed a cinematic metafiction. What marks this film as a metafiction are the creation and collapsing of two distinctions: the first, between first- and third-person perspectives on plot action; the second, between what we might call two levels or orders of represented fiction.

Let me consider first how La Femme de l'hôtel collapses the distinction between first and third-person perspectives. In literature, if a story is told from the perspective of a first-person narrator, then standardly there is no independent third-person perspective against which to judge what the narrator says. A firstperson narration means that what is narrated will be from the perspective of that one narrator, and indeed will be from the perspective of that narrator as a particular individual with distinctive psychological attributes. In the case of literature, we judge the accuracy of a first-person narration by discovering what we can about these attributes of the narrator: Is the narrator in a position to know the facts of the events she recounts? Do we have reason to believe the narrator is limited in her ability to make judgements about what she recounts? We have to infer what counts within the fictional world as the "objective" facts of the matter from what we learn about the narrator as a psychological entity.

What cinema provides, and what Pool makes use of, is the possibility that a first-person narration can coexist with a thirdperson narrative perspective. So in La Femme, we are initially confronted with both Andréa's voice-over, a voice-over which uses the first-person pronoun, in which she speaks of herself, her experience and her goals, while simultaneously we see images that need not originate from the perspective of that speaking narrator - though they are images of the city, and Andréa speaks of her experience of the city. We see images that represent for us something like what Andréa is talking about, but these are not images "coded" as "being seen through her eyes." The film puts immediately into place for us the distinction between first and third-person perspectives, associating the first-person initially with the voice, with the speaking subject, and associating the third- 
person initially with the cinematic image itself, with what is seen by the "camera-eye."

This is an important precondition for the second strategy put to metafictional use, the creation and the collapse of two distinct fictional worlds. La Femme de l'hôtel has a base-level fiction, a first-order fiction, in which Andréa, her principal actress (who is never named in the film), the mysterious woman they both meet (Estelle), and various other characters who work on the production of Andréa's film. But there is a second-order fiction in $L a$ Femme. We see scenes from the film that Andréa is making. Ordinarily, it would be a straightforward matter to keep these two fictional orders distinct, as it would be a straightforward matter to keep the first-person narrating voice-over distinct from the thirdperson perspective of the images we see. But Pool's metafictional twist here is to throw into question the relationship between fictional orders, shattering the coherence and continuity of fictional space and time, confronting us as spectators with the disturbing realization that we cannot be sure, as we are watching, what fictional order it is we are observing, or what authorizes and fixes the scenes we see. In this way, Pool throws into question the "objectivity" of both fictional orders in the film.

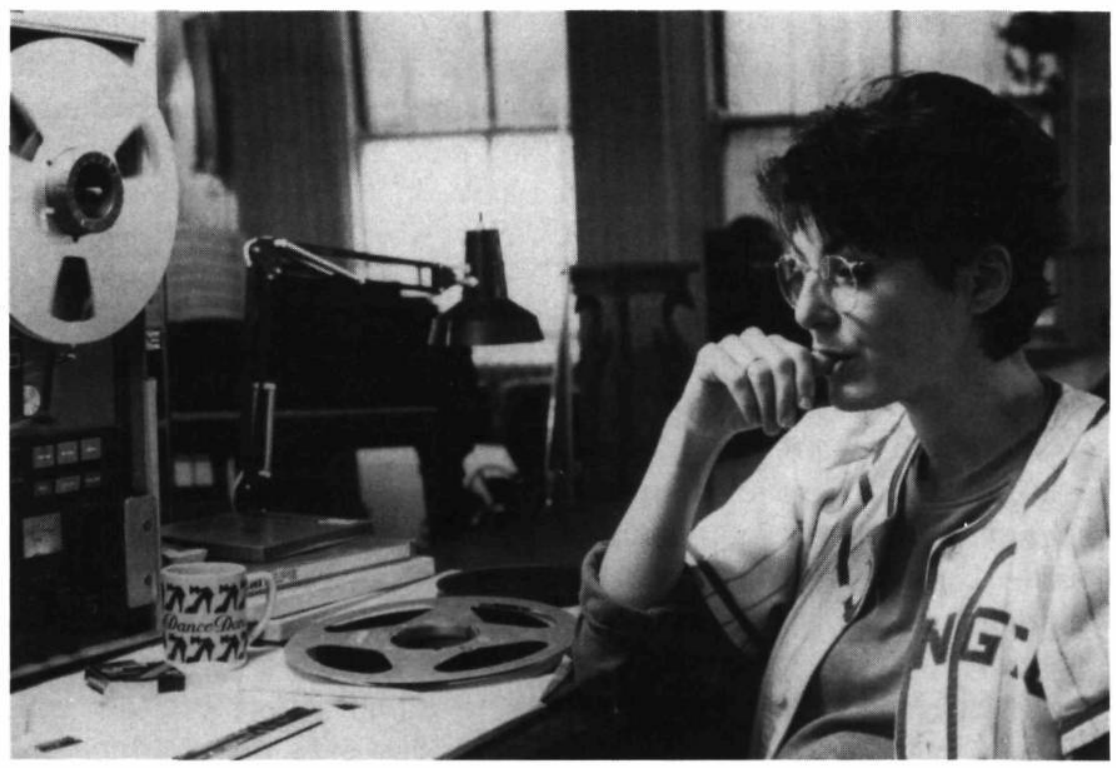

La Femme de l'hôtel de Léa Pool (1984)

Coll. Cinémathèque québécoise 
How does Pool achieve this collapse between the two perspectives and between the two fictional orders - between first and third-person, between the base-level fiction and its apparently "objectively" depicted fictional world, and the second-order film within the film? Two ways : one is by introducing scenes into the film — right from the beginning, I might add — which appear as though they must be shot from a third-person perspective, but which seem, initially, unmotivated by explicit plot information. These shots and scenes raise the question about just whether these scenes are, in fact, "objective" within the film, or perhaps whether they might be what I want to call an imaginative projection, in this case perhaps a visual representation of something Andréa is imagining. Some of the long shots early in the film of Estelle walking in the city are correlated to Andréa's voice-over describing the character she is trying to create. Andréa's description fits the image so perfectly we cannot decide whether the shot is an "objective" shot of Estelle or whether the shot depicts for us what Andréa is imagining.

The second way in which these different perspectives and levels within the fiction are deliberately collapsed occurs in the context of shooting Andréa's film, after she has actually met Estelle and discovered that this woman is the character she has been struggling so hard to imagine or invent, so that her meeting with Estelle throws totally into question the relationship between creating something original and merely recording something actual. There are several scenes in La Femme which appear initially to be actual parts of the first-order fiction - for example, the scene in the restaurant where the actress is consoled by the waitress, which could legitimately be interpreted as occurring "objectively" in the first-order fiction, since, as we have come to understand, Andréa's increasing preoccupation with Estelle leaves the actress feeling isolated, unhappy and inadequate. But this scene ends when we hear, in voice-over, Andréa's voice call "Coupez!" ("Cut!"), when we realize that what we have been watching has, in fact, been the actress playing the part of the character in Andréa's film playing the fictional character who is so much like Estelle that Estelle, too, in time, comes to worry about her own identity, whether perhaps she has lost her identity, whether she must watch the actress playing out scenes from her life in order to know about her own experiences.

I read La Femme as a film tremendously aware of the close connection between the actual and the imaginary - fiction itself might be seen as the actualization of the imaginary, or at least of the imagined. And it is a film that is tremendously aware of the 
difficulty of subjectivity, the difficulty of knowing oneself, or of being able to speak about one's identity. We see this in scenes where Andréa and Estelle talk about Estelle's life and experiences, in order that Andréa can better understand both Estelle and the central protagonist of her film. In these discussions, discussions which are neither solely about Estelle nor solely about the character in the film, both Andréa and Estelle use the third-person pronoun - they speak of "she" and "her". We know that Estelle is speaking about herself, but she does not speak of herself as "I" and "me". The difficulty of personal identity is captured here as a difficulty in language and positionality - the position of the self in the structure of grammar. In these subtle and profound ways Pool reflects on the relationship between our construction of ourselves as selves, and our construction of fictions as fictions emphasizing the significant role of language and imagination in the work of creation and description.

La Femme de l'hôtel is a marvelously rich and complex film, an exemplary metafiction because of its self-reflexive investigation of fiction and representation. Cinematic metafictions problematize realist film practices by underscoring the construction of both objective and subjective representations - the representations of the fictional world as well as the representations of psychologically distinct individuals through characterization. But not all of the films that challenge the traditional (social realist) criteria which seem to have defined the "canon" are metafictions of the same sort. I want to turn to the very different sort of metafiction exemplified by Bruce McDonald's Roadkill — a metafiction for which I have coined the phrase pararealism as a way of describing the twin problematizing strategies it employs. The first occurs at the level of the cinematic image in the film's parodic and self-conscious use of the visual style of various social realist film practices, both fictional and documentary. The second occurs at the level of story and emplotment, in which we again find the parodic contestation of linear-causal plotting and the equally parodic construction of character (with the sole exception of the film's protagonist, Ramona). I want to call McDonald's work pararealist to emphasize the fact that social realism, broadly construed, is the film's base point, but even while Roadkill has its roots in realism, what we get is a quirky, irregular, unconventional realism, a realism that cannot sustain itself, and is finally not interested in sustaining itself, but wishes instead to veer off in the direction of the parodic and the absurd. And in doing so, it, too, leaves behind any of the stable conventions of realist filmmaking practice, particularly the social realist "impression of documentation". 
Any discussion of Roadkill must emphasize its visual style. It is a film that presents itself to us in the first instance in terms of its visual style - indeed, in terms of its citation of a number of visual styles that are familiar to all of us as part of the stylistic heritage of Canadian cinema. The very fact that McDonald has shot the film in black and white refers back to our tradition of social realism, to the idea that what Canadian film cameras record in black and white will have the authority of documentary. ${ }^{2}$ The film begins in the documentary mode - indeed, in more than one documentary mode. The first section of the film is, of course, the nature documentary investigating the decline in the rabbit population of Northern Ontario, complete with omniscient third-person male voice-over. But we move from this style of documentary filmmaking straight to a particularly fine example of cinema direct: the Easter procession. This is reminiscent of some of the work Unit B (in some respects it recalls Les Raquetteurs and the early documentaries of Don Owen). We have a public, social gathering to mark a religious celebration. It shot with a handheld camera, complete with cut-in shots of spectators along the parade route, including Ramona, our fictional protagonist. Since this is in the style of cinema direct, there is no voice-over. If the sudden appearance of the filmmakers' van over the crest of the road breaks the internal coherence of the rabbit documentary, it is the soundtrack that breaks the internal coherence of the parade scene as an example of cinema direct, for the music we hear (and which we take to be located, within the film, as the music Ramona is listening to on her headset) is simply not consistent with the occasion of the Easter procession. And here already we have the signal of how the film will self-consciously subvert the very devices it is employing - especially the devices of social realism, in both its documentary and fictional forms.

Nowhere in Roadkill is this internal critique of social realism more apparent than in the film's construction of character: Ramona, herself, is an entirely plausible realist character. She is presented without parody. We even have access to her thoughts, reflections and plans through the device, since her diary entries are read to us in voice-over. Of course, as a true realist protagonist she is on a quest that will require her to use her wits and her resources to solve a mystery and complete an assigned task. However, all around her McDonald has placed characters who are not, strictly speaking, realist; they are parodic, cartoon-like caricatures - the diabolical rock promoter; the spaced-out rock band, pointedly called the Children of Paradise; Russell, the wouldbe serial-killer; the cab driver with delusions of grandeur that may 
not, as it turns out, be all that delusional. And the hilarity of the film comes from just this extraordinary juxtaposition of improbable characters with Ramona, our earnest, diligent, and altogether likable protagonist.

The emplotment of Ramona's quest - her task of finding the Children of Paradise and returning them to Toronto - is decidedly linear-causal and this at more than one level. The first linear-causal element is the journey itself: the trip from Toronto north (by cab!) to the Nicklebelt. The second element to reinforce the linear-causal plotting is temporal: not only are we informed about the passing of time, we know precisely what day it is throughout the film: the film takes place between Good Friday and Easter Monday, and through the device of the diary we are always informed what day it is, what Ramona has done, and what she intends to do. The linear-causal sequence of events seems to incline the film toward realism, but I want to suggest that the metaphorical and allegorical significance of the film's temporal setting - at this critical point in the story of Christ's death and rebirth - is yet another pararealist element which, along with characterization and some plot events I will discuss in a moment, defamiliarize realist cinematic practices. Indeed, however incomplete the parallelism, and however self-conscious the inversion of the Christ story in some of Roadkill's plot events, setting Ramona's quest for the Children of Paradise in the context of Christ's death and resurrection is one way in which the film combines pararealism with metafiction. For what this parallelism accomplishes is to remind us that the events of the film's plot are anything but the mere "capturing" or registration of objective actions, but rather the construction of a story whose significance depends upon the structure of the whole work and the kinds of narrative elements the work employs.

Two significant metafictional elements combine with Roadkill's pararealism. These are elements which we have already identified in La Femme de l'hôtel, where they were central. Here, they are significant but not the principle themes of the film. The first, which we have seen already, is the idea of a film-within-a-film, which is characteristic of one kind of self-reflexivity we find in cinematic metafictions. In Roadkill, of course, our filmmaker is not the sensitive and reflective Andréa; rather, we have the extraordinary caricature that Bruce McDonald gives of himself, since he plays Bruce Shack, the documentary filmmaker with ambitions to break into the mainstream. The second device is the collapse between distinct levels of the fictional world. In $L a$ Femme, this collapse was easier to trace because of the signals Pool 
provides to mark for us our position vis-à-vis the two levels of fiction within her film. McDonald, who is more interested in parody, does not give us such clear "markers, and leaves us to puzzle over many of the events of the film, events which are presented to us, visually, as perfectly straightforward, objective occurrences in the fictional world of the film, but which are, in and of themselves, inherently implausible (I don't use this term pejoratively: the implausibility is essential to the film, not a fault). Examples include the trio of buskers singing on a dirt road, or the apparition of the bicycle-powered hot dog cart in the middle of nowhere, bringing food to our penniless, starving heroine. McDonald doesn't collapse the distinction between what counts as "objectively" real in his fictional world in the same way Pool does : he does it by the introduction of characters and events which are fabulous, fable-like, magical, impossible; elements that break with what we would expect to count as plausible in the fictional world which looks - through its social realist visual style — pretty much like our actual world, and in which, on that logic, actions should occur that are about as plausible as similar sorts of actions occurring in our world.

In $\mathrm{La}$ Femme, as I have mentioned, we are presented with images which seem, initially, to be objective elements in the firstorder fiction, but which are later are revealed as images from the second-order film-within-the-film that Andréa is making. McDonald includes one comparable shot in Roadkill. Since McDonald, as Bruce Shack, is a character in the fiction - in fact, a filmmaker within the fiction - we become quite accustomed to seeing him with his camera, filming things. We also become accustomed to seeing the images he films, since they are "coded" for us by being inset in the film frame. So when we see him in Ramona's motel room - with her asleep on the bed - standing behind the camera and apparently filming something that is offscreen, we initially assume that the source of the image we are seeing is another camera, recording Shack/McDonald. This shot is not "coded" for us as one that Shack is actually shooting. But a slow pan begins, and we discover that what we have been watching is Shack/McDonald (as character, as director) shooting into a mirror. The image we have seen initially - Shack behind the camera, Ramona asleep behind him - is the mirrored shot Shack/McDonald has filmed. Here, in an economical but totally self-reflexive fashion, we find the director inscribing himself as cameraman within the fictional world of the film.

Roadkill's most significant pararealist sequence must be the final performance by the Children of Paradise. ${ }^{3}$ This is an extremely 
complex and disturbing sequence, perhaps because the audience has come to accept and enjoy the parodic, absurd and improbable characters and events which have made up the film's narrative thus far. The film has allowed us to empathize not only with Ramona, but also with the cab driver, the neophyte serial killer, the lead singer of the Children of Paradise, Bruce Shack, and others. There is nothing to prepare us for the massacre at the bar, during which virtually every central character is shot and killed. The shooting itself is depicted in a thoroughly non-naturalistic way. The massacre is presented in the context of a stage performance. It is played out for the audience at the bar, who appear to find the performance unusual but thoroughly entertaining. Everything from the way the shoot-out is filmed (shot, lit, edited) to the fact that we can see the bags of theatrical blood under some of the victims' shirts, leads us to believe that the shoot-out is the performance, and that the characters will jump up at the end and take a bow. But in the film's most unexpected twist, the dead characters are left dead. There is no resurrection. This scene, which the film has lead us to imagine should not be taken seriously, must be taken seriously because it does not allow us a comedic resolution. And for this reason, the scene perplexes and confuses audiences, who find they no longer know how to think about the film.

In the course of Roadkill, the pararealist strategies of emplotment and characterization have defamiliarized the conventions of social realism, have defamiliarized the conventions we would expect to find in a film with Roadkill's particular visual aesthetic. Most importantly, Roadkill refuses to let us believe in the social realist "impression of documentation", though this is what its visual style would lead us to suppose we could do. And just when we have gotten used to this idea, accepted the notion that a film with this visual aesthetic is not attempting to create an "impression of documentation", McDonald presents the Easter Monday massacre in a totally denaturalized way which, unexpectedly, turns out to have the authority of documentation, since within the fictional world of the film everyone who has been killed stays dead.

In Pool's film, the metafictional self-reflexivity is presented explicitly, in the dialogue of the characters as they speak of their concerns over their identities and experiences. Cinematically, this metafictional self-reflexivity is presented to us diachronically, sequentially. The film collapses its two fictional orders. The "base-level" fiction, in which what we see is an "objective" part of the fictional world, is problematized by the incorporation of scenes 
from the film-within-the-film. Sequence by sequence, the status of the various images (their status as first-order or second-order) is either revealed to us, or not. McDonald's pararealist selfreflexivity works in a rather different fashion. The metafictional or pararealist elements of Roadkill are presented in the same space and time as the realist elements. Both films leave us, as spectators, with questions that just cannot be resolved about the fictions, questions that must remain undecided on the basis of all the evidence the films present.

The undecidability of Pool's film occurs most obviously in the last two scenes of the film: the first of these, in which the nameless actress, reenacting an earlier scene of Estelle's, goes to the train station and boards a train; the second, when we see Estelle herself on a train. For there is no answering the question: which order of fiction are we watching here? Throughout the film we have eventually been given clues to answer that question. But in these last two scenes we do not know whether, in the scene with the actress, we are watching a scene from the first-order fiction, in which the actress, herself, leaves Montreal by train (say, after filming Andréa's film is completed), or whether we are watching a second-order scene, in which the actress is simply acting a scene from Andréa's film. The last shot of the film is equally undecidable. This shot, of Estelle on a train, could be a shot from the first-order fiction; but it could equally possibly be an imaginative projection of Andréa's; since Andréa knows Estelle has left, this might be how she imagines Estelle's departure. The dilemma about which order of fiction we are watching is left unresolved in both cases.

The postmodernist variant McDonald uses in Roadkill is rather different, because the undecidability comes as a result of there not being an "objective" base-level fiction against which to judge the metafiction. The presentation of all the improbable characters alongside Ramona, especially in the context of the massacre of the band during their one-night only performance, destroys for us any sense that there is a base-level fiction against which to contrast the film's metafictional elements. Both La Femme and Roadkill contest the fundamental conventions of realist cinema, and thus of social realist cinema.

Patricia Rozema's White Room, like La Femme de l'hôtel, is a metafiction, but unlike La Femme it is self-reflexively about storytelling without being self-reflexively about filmmaking. Though White Room is not an example of pararealism - the stylization of its images forbids it - there is one important point of connection between Rozema's film and McDonald's: the anti-realism of their 
stories and characterization. White Room, like Roadkill, is a film concerned with story-telling as fabulation, story-telling as the construction through time of a fictional world in which the principle conventions of realist narrative practices do not (and need not) apply. We discover this aspect of Rozema's film immediately after the opening credits, when a female voice-over establishes for us the fairy-tale quality of the narrative, and indeed introduces us to the filmic action as a tale being recounted for the audience : "Once upon a time," the voice says, "there was a young man who lived a very exciting life. The problem was, it was all in his head ... and when he tried to put words on it, it all slipped away."

White Room is a film which examines the nature of artistic creation and expression, the various aspects of human experience that threaten either to transcend or to escape capture in representational systems (language, music, film, etc.), and the sometimes translucent boundary between fantasy and reality. The actions of the film's central characters - including our "hero", Norman Gentle, and his love, Jane - are presented as actions within a fable, not as actions within a realist plot. We must not expect, therefore, that the actions of characters will "make sense" in the way we expect of realist plots - where actions standardly "make sense" if they flow logically from one another and can be accounted for in terms of the characters' goals and desires. The sort of "sense" made by White Room is much closer to the sort of "sense" made by fairy-tales or parables.

The mediating role of the story-teller/narrator is crucial to our understanding of the film's actions as elements of a fable. The first and perhaps most obvious function of the narrator is to describe and contextualize plot action for us, establishing transitions between plot elements ("Then one night he heard a sad song...") and offering information about the characters that we could not necessarily discover just by observing them ("Norman the gentle slipped into the darker side of curiosity"). In this sense, the narrator's function might initially appear to be quite like the omniscient narrating voice of realist or naturalist fictions and documentaries. But of course this omniscient narrating voice is not the omniscient narrator of realist filmmaking, and "Once upon a time" is not an opening available to realist fictions. The narrator of White Room is not simply describing some "objective" set of actions for us. We must think of the narrator as fabulator, as the creator of the tale which we are witnessing. The role of narrator as fabulator undermines the illusion that the characters and actions we are watching are simply being "recorded", or that the fictional world of the film is constructed according to the conventions of 
verisimilitude. The narrator calls to our attention that this story is created in the telling, as all stories are created in the telling. Metafictions are, necessarily, anti-realist, because they call attention to themselves as narrative constructs. What we find, whatever metafictional or pararealist strategies might be adopted by a non-realist, anti-realist or pararealist film, is that the governing ideas of realism - especially the idea of verisimilitude, that the film is striving to achieve an "impression of documentation" - become irrelevant to the objectives of such fictions.

We might of course have guessed this from the way the film is shot. The film stock used in White Room offers us extremely saturated colours. Most striking are the vibrant reds and blues, though Rozema has made equally impressive use of green and white. But the anti-naturalism of the film's images is not limited to the extremely saturated palette of the film stock. There are as well the extraordinary Toronto cityscapes, the hyperreal combination of choice of location and means of shooting it, for example Zelda's place in the environmental wasteland or the helicopter shot of the newsstand. Editing becomes a factor in this hyperreal aesthetic, as we see in the sequence of shots when Norman is pursuing Jane after the funeral - though of course perhaps she is pursuing him. These shots are as much concerned with the composition of the image as they are with depiction of plot action. Visually, White Room foregrounds its constructedness, its ongoing construction, in a manner that parallells perfectly the function of the narrator as fabulator. At the level of the shot, as well as at the level of editing, White Reom announces its self-consciousness about its artefactual status: each shot reminds us that this shot is constructed as part of a fabulous story, as part of a fable.

That this film is self-consciously constructed and presented as a fable means that we must think of Norman Gentle's actions as we would think those of a fairy-tale character, that is, symbolically, not naturalistically. Norman is an innocent young man, and dangerous because of his innocence. This is something that is understood by the female narrator, but also recognized by the film's two most important female characters, Zelda (Sheila MacCarthy) and Jane (Kate Nelligan) - particularly Jane, who, speaking of Norman, says "I don't know why I'm attracted to helpless people." That Norman is helpless is part of the paradox of this metafiction, because Norman, the character who must act to save or rescue Madeleine $X$ (Margot Kidder) and Jane, is singularly unsuited to action. 
The film's self-consciousness about the conventions that organize narratives is worked out both within the fiction and by means of the perspective offered by the narrator. Just like the female narrator, both Zelda and Jane remind us about the significance of narrative conventions - the significance, that is, of the form stories must take. Norman tries ineffectually to find words to describe the rape and murder of Madeleine $\mathrm{X}$ - an event he has observed without being able to intervene in it. Not only must he find words to describe what he has witnessed, but also to explain why he did not act — indeed, to justify his inaction. His first attempt to do this is an essentially linear and straightforward account, the poorest attempt at autobiography. Zelda remarks that this sort of structure does not seem to give the story a point. What is needed, she suggests, is a love interest, a dramatic and emotional focus. At just this point, the film itself provides a love interest for us, and for Norman, in the figure of Jane. It is critical to our understanding of White Room that the romance, the love story, is presented as a convention of fiction.

Some of Jane's dialogue also reminds us of the conventional requirements of stories, and of love stories. When she decides to take Norman into the white room, in order to explain about herself and her connection to the murdered woman, she says, mockingly: "Every story needs a tender love scene." Norman replies : "This isn't a story," to which Jane responds, "Yes, it is." Norman's denial is understandable; few fictional characters acknowledge through their own dialogue their fictional status. But Jane's response is self-reflexively metafictional, since by means of this exchange of dialogue we are again reminded that the fiction as a whole is a story, and as well that the accounts the characters offer of themselves and each other are, also, stories. This exchange is also deliberately ironic, since what we are about to witness is far from the sort of thing we would expect to see in a "tender love scene."

Story-telling is important within the fiction as it is important to the structure of the narrative as a whole. Within the fiction, this is clearly true for Norman and for Jane, as we see in their attempts to explain themselves to each. Norman's monumentous, magical "gift" to Jane, the thing he has finally "made" for her, is the story he has been trying to find words to tell, the story that explains how he came to be the passive witness of Madeleine X's death, the story of his chance meeting with Jane and of his love for her. But this gift precipitates the destruction of their relationship. And Jane, when she finally feels compelled to reveal to Norman the as yet unconfessed truth of her past, precipitates her own destruction. 
Every fairy-tale requires the rescue of the princess by the handsome knight, and White Room is no exception. It is a convention of the form that the knight and his princess live happily ever after. The narrator tells us explicitly that this is the context for the final scenes of the film ("And finally Norman raced back to rescue his princess"). Rozema appropriates this convention of rescue and reunion, but turns it against itself. For as Norman returns to the white room, he finds Jane dead, her throat slashed by her own hand. The narrator explains this unanticipated departure from convention by saying that Jane's "heart had been broken", that "her fear of the world was much too great" for her to live. So for a second time in the film Norman has been indirectly responsible for the death of a woman : responsible because he could not act or even call out during the murder of Madeleine X; responsible because his innocent desire to make Jane the gift of his story led to the revelation of her real identity, the very thing she could not bear. But fairy tales cannot end with the princess's suicide. Love stories cannot end with the beloved's neck slashed, with a pool of blood staining the floor of the white room. For Norman, who is again confronted with his inability to act appropriately to help those around him, only one solution remains. That solution is metafictional and self-reflexively non-naturalistic. Because, as the narrator advises us, Norman "did not know how to live in a world with endings like this," he turns back time, and "[writes] himself a much kinder ending to the story."

The double ending to White Room must be understood in the context of fabulation, of story-telling. There is no such thing as turning back time within the standard conventions of realist and naturalist fiction - granting the exception of some highly specialized cases (It's a Wonderful Life; science fiction). And certainly neither realist nor naturalist fictions can accommodate a wholescale revision of events because it has been willed by one of the fictional characters. Realist and naturalist fictions presuppose one objective temporal order. Actions are related to one another, within realist and naturalist fictions, by means of a principle of plausibility. Actions within the fictional world of a realist film are judged to be plausible provided they are causally connected to one another in more or less the same way comparable actions would be connected in our social world. There is no precedent in our actual world for individuals who bring about a revision of events by mere act of will. Such a possibility can only occur in fiction, and can only occur in fictions where the powers of the characters are of a different order from the sorts of powers enjoyed by social agents. 
By foregrounding the artefactual nature of all fictions, metafictions abandon the primarily sociological function of realist and naturalist fictions. Especially in the context of the Canadian cinema, if realist fictions are taken to tell us something about our objective social existence, about ourselves nationally and/or culturally, metafictions inquire into the epistemological bases for any such representation. I have indicated that one of the characteristics of both La Femme de l'hotel and Roadkill is the way in which what counts as "objective" within the fictional world is problematized by metafictional or pararealist strategies. In both cases, though in different ways, attention is drawn to story-telling, to the artefactual nature of characters and plot action, and to the various epistemological functions of artistic media. In a way that is quite different from either of these films, White Room also draws our attention to story-telling, to the allegorical significance of characterization and character action, and to the ways in which the significance of any narrative artefact is a function of its formal concerns and structure. White Room reminds us that the truths of fiction are of a particular kind, dependent upon the intentional ordering and structure which gives meaning to represented actions. Fictions are ordered as we will them to be ordered; even such generally accepted values as mimesis or verisimilitude are means by which an intentional order is given to events - an order which allows us to understand their significance. Realist and naturalist fictions also share this intentional ordering, but they do not draw explicit attention to it, preferring, as it were, that we read "through" the form of the representation to what is represented. Metafictions, in any number of different ways, require us to focus both on the form of the representation as well as on what is represented; they encourage us to interpret what is represented by means of what we learn from the form of the representation.

What of the "canon", then? Ought we to include the likes of $L a$ Femme de l'hotel, Roadkill and White Room? On the basis of what sorts of criteria could we admit these films alongside of more conventional realist films like Anne Wheeler's Bye, Bye Blues or Bill MacGillivary's The Vacant Lot, or any other realist films we were interested in considering? Any successful answer seems to require a closer examination of the question. When we talk about a national "canon", or indeed of several national "canons", it seems we are trying to identify exemplary works, models of the best sorts of films that have been produced. At least, when Leavis wrote The Great Tradition, that was what he was trying to do for the field of English literature, and I take it that the same sort of thing is behind the construction of cinematic "canons", including the construction 
of a "canon" of Canadian cinema. But we should recall that Leavis' canon was driven by authorship - by the novels of four writers, and not in the first instance by the novels themselves, independently of the homogenizing moral vision of their authors that, for Leavis, the novels demonstrated. ${ }^{4}$ Yet it is far from clear that a "canon" of Canadian cinema must be driven by authorship in quite the way Leavis' canon is driven by it. Nor is it clear that a "canon" of Canadian cinema must be driven by the desire to identify a particular moral vision, which is also central to the Leavisian notion of a canon and its function within a national literature.

In a Canadian context, heterogeneity rather than homogeneity might come to be one of the key features of the films that comprise any "canon" worth naming and teaching - heterogeneity of mode, heterogeneity of form, heterogeneity of purpose. In this paper I have restricted myself to a discussion of fiction filmmaking, but I do not wish to give the impression that I believe only fiction films ought to be seen as exemplary. I have argued elsewhere that the interconnection of documentary, fiction and experimental filmmaking practices must be fully acknowledged if we are to have a thorough understanding of the Canadian cinemas. 5 But even if we momentarily restrict our consideration to fiction filmmaking, what we discover through the examination of metafictional and pararealist tendencies in the films of the $80 \mathrm{~s}$ and $90 \mathrm{~s}$ is that the criteria for identifying what is "canon" material cannot be social realist criteria. The "impression of documentation" can have no privileged position in determining the best or the most exemplary Canadian films. I think this should have a liberating effect on our consideration of Canadian film.

That the "impression of documentation" should not have a privileged position in shaping the "canon" does not repudiate the value or importance of Canadian films which are examples of social realism. In fact, I think recognizing the degree to which "social realist" criteria are not the appropriate criteria for deciding what is canon-worthy might have a positive influence on the reexamination of films that are explicitly examples of cinematic naturalism. Bruce Elder once wrote that the only thing of interest about Nobody Waved Goodbye - itself of course a splendid example of cinematic naturalism - is that it was made here. 6 This judgement suggests that some examples of social realism are not much valued by Elder. Elder also thinks there is something wrong with Goin' Down the Road, because, on his reading of it, the film fails to organize itself around either the social realist episodic narrative structure of cinematic naturalism or around a plot driven primarily by dramatic action, conflict and resolution. While I find 
Elder's reading of Shebib's film suggestive, we must also note that it is prescriptive. It says, in effect, that Goin' Down the Road is flawed and should have heen otherwise (either episodic or dramatic). This would only be true if we felt that Canadian cinema's most exemplary films ought to be "pure" examples of one mode or form. The case of metafiction suggests, on the contrary, that self-consciously - and arguably even unself-consciously non-unitary film forms are themselves interesting, and not necessarily because they give us even so much as the impression of documenting some aspect of our cultural or social experience. ${ }^{7}$ Still, much of the writing about Canadian film does value social realism and the ideology of documentation that it embodies.

Which leads to a realization about these vague things I have called "criteria". What we find is that any "canon" which includes a preponderance of social realist films is a "canon" where descriptive criteria have come to stand for evaluative criteria. The social realist criteria I discussed at the beginning of this paper are descriptive : they say what general characteristics a film will have if it is to be classified as an example of social realism. There is nothing evaluative about such criteria as a coherent spatio-temporal fictional world or psychologically coherent characters until these descriptive criteria are applied against films which do not employ these conventions of emplotment or characterization - and even in such cases, they are not truly evaluative, since they only allow us to say what such alternative conceptions of plot or character are not (the possibly pejorative implications are not, I want to suggest, genuinely evaluative).

But "canons" are historical constructs. The values that inform their construction are often tacit, often themselves rooted in particular historical conjunctions. In our own case, then as now, critics write about films that interest them in particular ways and for reasons they believe are worthy of discussion. The metafictional and pararealist films of the $80 \mathrm{~s}$ and 90 s are only an instance of the historical specificity of critical undertakings. To argue for the inclusion of these films in a "canon" would mean changing the criteria of inclusion; to argue for their exclusion would mean that criteria appropriate to the $60 \mathrm{~s}$ or $70 \mathrm{~s}$, say, or criteria appropriate to one dominant film mode, are used to judge against films which problematize those very criteria. What seems necessary is a way out of this impasse. What we need is not a "canon" but a syllabus.

There are any number of problems buried in the notion of a "canon". One problem appears whenever the values which canonized works are thought to exemplify are taken to be 
ahistorical and universal (think of Leavis). A canon demonstrates what Ricœur would call an "achronic logic" — a logic outside of time. ${ }^{8}$ It seems essential that we recognize the historicity of canons, and the historicity of the judgements that construct canons. A second problem is that what are presented as values are occasionally not values at all, but preferences, quirks, enthusiasms, interests. This is inevitable and unexceptional, if only we recall that criticism is an historical practice. A third problem, which I think needs greater examination in the context of the Canadian cinemas is one pointed to recently by Trevor Ross in his examination of literary canons. ${ }^{9}$ Even assuming we could settle on a canon of works that exemplify the best work in the Canadian cinemas, what we would find is that such a canon, by its very nature, does not allow us to discuss the specifically canonical elements or features of the films that we canonize. By grouping films (or other artefacts) together in one canon, we unexpectedly find ourselves without the means to say what exactly it is about any of them that makes them worthy of continued discussion and analysis.

A syllabus, on the other hand, returns filmmaking and critical practice to history - to a history that is not uniform or homogeneous. A syllabus allows us to examine the changing narrative strategies and alternative epistemological and social functions of our cinema - changes which we see prominently in the recent metafictional and pararealist films, changes which challenge our current expectations and which offer us alternative perspectives on earlier work. A syllabus would arguably include films that are worthy of discussion and analysis even if they are not thought to exemplify "the best" works we have produced. We would not have to leave Nobody Waved Goodbye off of a syllabus because of its unsatisfactory last-minute revelation of Julie's pregnancy. We would not have to leave off Goin' Down the Road because it is a film that, at least on Elder's view, is flawed conceptually and narratively. Nor would we have to leave off a film like Why Shoot the Teacher because it was unfortunate enough to be released in the same year as Allan King's first fiction feature, Who Has Seen the Wind, which for a number of documentable reasons pushed Narizzano's film to the margins of critical consideration. Most of us who teach Canadian cinema work in the first instance with a syllabus and not with "the canon." A syllabus is a modest proposal, but one which promises greater productivity than a canon.

Carleton University 


\section{NOTES}

1 See for example R. Bruce Elder, Image and Identity: Reflections on Canadian Film and Culture (Waterloo: Wilfred Laurier University Press, 1989).

2 The phrase, "the authority of documentary," is Peter Harcourt's.

3 The marquee says they will be appearing "for one night only," a phrase with prophetic significance as the plot develops.

4 F. R. Leavis, The Great Tradition: A Study of the English Novel (Garden City, N.Y.: Doubleday and Company, 1954).

5 Deborah Knight, "Exquisite Nostalgia : Aesthetic Sensibility in the English-Canadian and Quebec Cinemas," cineACTION! n. 11 (Winter 1987-88) 30-37.

6 R. Bruce Elder, "The Cinema We Need," Documents in Canadian Film, ed. Douglas Fetherling (Peterborough : Broadview Press, 1988). Elder writes : "Nobody Waved Goodbye, for example, strikes me as a film that is interesting only for the fact that it was made here" (266).

7 It seems to me that a crucial case in point here, but one taken from the realm of documentary, would be Martin Duckworth's The Wish. Peter Harcourt's reading of the film, "Cinema, Memory, and the Photographic Trace," investigates the ways in which Duckworth, apparently setting out to construct an "objective" account of his twins' vacation with their grandparents, "disrupts the apparent transparency of his own documentary practice." See Seth Feldman, (ed.), Take Two (Toronto : Irwin, 1984) 229-235.

8 See for instance Paul Ricour, Time and Narrative, trans. Kathleen McLaughlin and David Pellauer (Chicago : University of Chicago), three volumes.

9 Trevor Ross, "Making Allowances : Why the Real Problem with Canons is not Canonicity," manuscript.

\section{WORKS CITED}

Pevere, Geoff. "In Others' Eyes : Four Canadian Films Come Home From Cannes." cineACTION! n. 11 (Winter 1987-88).

Waugh, Patricia. Metafiction: The Theory and Practice of Self-Conscious Fiction. London: Methuen, 1984. 